\title{
Unfamiliar Familiars: On Non-human Alienation
}

\author{
TONI JOHANNES KOIVULAHTI \\ Faculty of Theology, University of Helsinki \\ toni.koivulahti@helsinki.fi
}

\begin{abstract}
The article focuses on Karl Marx's notion of alienation and its application to questions of ecology. By contrasting this notion with its existential critique made by Paul Tillich, as well as to Rob Nixon's concept of slow violence, I demonstrate how the notion of alienation can be applied to non-human species as well. I will first describe the structure of alienation by examining the theory that Marx provided originally in the Economic and Philosophic Manuscripts of 1844; by relating alienation to slow violence, I will then show how alienation can be applied to various environmental and non-human spheres. Reflecting on this through Paul Tillich's critique of Marx's theory of alienation will enable me to consider the possibility of using theology to traverse teleology. By using Tillich's nonteleological conception of theology, I will reconsider the idea of alienation from a standpoint which takes the existential condition of both humanity and non-humanity into deliberation. Finally, I will briefly bring Tillich and Marx into dialogue with contemporary thinkers, who have recently examined similar questions. This shows how the application of the theory of alienation allows us to re-examine various current dilemmas of inter-species encounters.
\end{abstract}

KEYWORDS: alienation; slow violence; Marxism; Tillich; animals 


\section{Introduction}

It is easy to find on the internet a video of a female sea turtle trying to nest on a beach full of plastic. She tries to dig into the sand with her flippers amid metal pipes, discarded flip-flops, plastic bottles, and various other kinds of rubbish. Barely able to dig a hole in sand full of marine debris, she lays her eggs in a pile of garbage. Another scene from the video shows hatchlings scrambling around in a pile of trash. As sea turtles usually lay their eggs in sand, the introduction of solid objects, such as pieces of Styrofoam, plastic, glass, or metal, present a disorienting prospect for the hatchlings as they struggle to find their bearings in a world moulded by humanity.

The encroachment of human constructions on non-human habitats is a distinctive feature of our time. Even the most remote places in the world are currently being reshaped by human actions. To examine the question of non-human animal interactions with a world increasingly being shaped human activity, I will approach the question from the perspective of alienation as explained by Karl Marx (1818-1883). In particular, I will focus on alienation via its description in the Economic and Philosophical Manuscripts (1844), and a complementary but critical version of it by the theologian Paul Tillich (1886-1965). I will begin the enquiry from the perspective of humans, then examine and draw parallels to non-human animals. ${ }^{1}$

The problem of alienation is a central theme of many recent applications of Marx's theories to the problems of ecology. Prominent examples include John Bellamy Foster's book Marx's Ecology: Materialism and Nature and Paul Burkett's Marx and Nature: A Red and Green Perspective. These approaches do not, however, expand on Marx's theory of alienation, nor do they provide a framework whereby one could apply Marx's theory of alienation in a broader, or perhaps in a different, sense. In this article, I will explore the concept of alienation by reading it alongside an existential critique by Paul Tillich and the concept of slow violence proposed by Rob Nixon. In doing so, I will demonstrate how the concept of alienation can be used to analyse interspecies encounters within the framework of material production and how Tillich's examination of the concept provides a different perspective on such encounters, one which makes possible an entirely different view of the problem. Hence, I will show how the concept of alienation can be applied to current problems of human and non-human encounters

1 I refer to a variety of non-human animals in this article; however, this does not mean that the discussion is exclusively limited to the examples provided or to specific non-human animals. One of the claims of this article is that the concept of alienation is a tool of analysis that is scalable. Therefore, the modes of alienation are also scalable to the ways different beings react to their environment. 
and, by recasting them as slow violence, how an analysis of alienation can open new vistas to current dilemmas. In returning to two thinkers who were born in the $19^{\text {th }}$ century, my aim is to demonstrate their continued relevance to modern discussions on interspecies questions. In addition, I will at the same time show how both thinkers have pre-empted many current developments in society, which they sought to think about in their time in a manner relevant to current ethical problems.

The aim of this article is to examine how the Christian existentialism of Tillich and Marx's early thinking on alienation can be aligned with the ethics of interspecies encounters, and how reading these thoughts in dialogue with one another can offer an approach that combines the political acuity of Marx with the ethical and existential vision of Tillich. Aligning these two thinkers can help us use the concept of alienation to better understand the complexity of non-human animal relationships to their environments.

The question of alienation is particularly relevant to the texts that Marx wrote in his youth. The French philosopher Louis Althusser $(1971,51-53)$ wrote already in the 1960s about how all discussions on the various phases of Marx are political discussions. According to Althusser, the return to the early texts of Marx includes an attempt to undermine Marxism-Leninism from within Marxist theory. The question, according to Althusser, has to do with whether the early works of Marx already fully realized Marx's philosophy or whether his later works represented the "real" Marx. Althusser himself considered "Young Marx's" thinking as imprisoned by its contingent origins, while his later thinking was free of the "gigantic layer of illusions" of his youth (Althusser 1971, 83). Althusser $(1971,61)$ writes that the self-consciousness of Marx shifted after the publication of his 1844 manuscripts and became fully realized in his mature works. For us living after the end of the era of "Marxism-Leninism", the political struggle for the soul of Marx might not be as relevant as it was in the 1960s. It is, however, important to note how discussions on the different phases of Marx's thinking are not neutral regarding the entirety of Marxist thought.

Because Althusser took a somewhat dim view of the young Marx, he also viewed his early thinking merely as a transitional phase in the life of the great thinker. Therefore, he also viewed the concept of alienation that Marx employed in his youth as irrelevant to his later material and considered his later uses of the term either as ironic or as substantially different in content to his early texts (Althusser 1971, 249). Other Marxist philosophers have taken the opposite position. For example, Lucio Colletti has treated the phenomenon of alienation as being identical to fetishism in the later thinking of Marx (Colletti 1992, 49). As a full exegesis of Marxist thought is not possible within the 
scope of this article, I will limit my discussion mostly to the manuscripts of 1844, which deploy and define the concept of alienation directly, while being entirely aware that a fuller examination of the history of this concept in Marx's works would yield further interesting and important results.

I will begin by examining Marx's concept of alienation and contrasting it with that of Tillich, while also examining how he conceived of the alienation of humanity from nature. After this, I will discuss how the concept can best be applied to non-human animals. By showing how Marx's ideas can be applied to non-humanity, I will be able to analyze how the processes of alienation can lead to violence. This will lead me to further analyze the concept of slow violence espoused by Rob Nixon, and argue that alienation from nature of both humanity and non-humanity is a form of violence. Reflecting on this idea through Paul Tillich's revision of Marx's theory of alienation will enable me to consider the possibility of combining the ideas of existential theology with materialist Marxism. By using Tillich's existential conception of theology, I will reconsider the idea of alienation from a standpoint that takes the existential condition of both humanity and non-humanity into consideration. Finally, I will briefly bring Tillich and Marx into dialogue with each other. This will allow me to show how the application of the theory of alienation allows us to re-examine various current dilemmas of interspecies encounters.

\section{The Concept of Alienation}

Marx and Tillich conceptualized alienation in different ways. A central difference between them is that Marx's conception is reducible to material explanations, whereas Tillich's idea derives from a religious and existential background. Neither connected the concept explicitly to non-human alienation. However, combining the thinkers' ideas on alienation is not a synthesis of polar opposites. Both built their ideas partly on shared predecessors. This should be examined briefly before moving on to describe their differing concepts of alienation.

Although the immediate influences of Marx's theory of alienation are usually traced to Hegel, Feuerbach and English political economy, the origins of the concept can be traced to what István Mészáros (1970, 27-28) calls "Judeo-Christian mythology". Mészáros $(1970,31)$ further claims that Protestantism was pivotal to the analysis of alienation because it focused attention on the analysis of practical day-to-day issues, and therefore it secularized the questions of estrangement. Although the theory of alienation carries with it this kind of historical baggage (according to Mészáros), I claim 
that such baggage is a testament to its continued relevance, as it can describe human experience in transgenerational terms, and I will later show how it can be applied also to interspecies modes of experience.

According to the German Lutheran theologian Paul Tillich (1991, 199), although the Bible does not specifically mention the concepts of estrangement or alienation, it metaphorically alludes to both in various ways. As examples, he cites the eviction of Adam and Eve from the Garden of Eden, the Tower of Babel and the aggression of humanity against nature and each other, among other analogous symbols of the breaking down of the unalienated state of humanity. For Tillich, alienation, or estrangement, signifies a division from what we essentially belong to. This separation is threefold: separation one experiences from other individuals, separation from oneself, and separation from what Tillich calls "The Ground of Being", that is, the basic human trust in the divine (Tillich 1966, 156). For Tillich, the problem of alienation has both a material component and an existential component, or to be more precise, they intersect and influence the other. In this sense, Tillich combines what Mészáros called Judeo-Christian mythology with material concerns about our quotidian existence. Mészáros (1970, 14-15) lists the four main aspects of Marx's concept of alienation in his classic book Marx's Theory of Alienation. The four aspects (as outlined by Marx in the Economic and Philosophical Manuscripts) are the alienation of humanity from nature, the alienation of humanity from itself, species-being alienation (i.e. alienation from the transformative and creative capacity of humanity), and humans' alienation from one another. Although for Marx the basis of human existence is material, while for Tillich it is at least in some way spiritual, the overlap between the young Marx and the later Tillich is significant. Both view alienation as something that estranges human beings from each other and individuals from themselves and from the sustaining powers of what could be described as "human nature", although there are obvious discrepancies between their views on how to define "human".

Marx (1992, 323-324) wrote in the Economic and Philosophical Manuscripts that labor produces itself along with its products. This means that the producing laborers become products themselves. The production of objects devalues the manufacturers, who become commodities akin to objects. Marx goes on to state that the object of production turns into "something alien" for the laborers and comes to embody the labor that was put into it, thereby gaining an independent power apart from its creator. This leads to a perverse situation wherein the workers who have sold their work are in bondage to this externalised labor and their reality is diminished by the process. The workers are therefore alienated from their labor. This turns into a vicious circle 
whereby the laborers produce commodities that sap the life from them, and diminish them, thereby at the same time becoming more and more alienated by these very same commodities, which exert a power over them. The inner life of such workers therefore becomes increasingly poorer as they are forced to continually validate their life through these external objects.

Marx $(1992,328-329)$ states that the alienation of labor is the root cause of other forms of alienation. The fact that humanity must refashion nature for capitalism to survive means that nature becomes the object of labor and is lost as a part of human experience. By being alienated from the product of their labor, laborers are at the same time estranged from the external world, and thereby from nature itself. Because labor is in this way alienated, the workers lose their sense of enjoyment and engagement with their work and can only hope to recover it from the selling of the product or labor time. Thus, the workers become alienated from themselves via the process of losing the coordinates or the central focus of their work. According to Marx, the objects of human labor are a part of the way humanity as a species experiences itself in the world. Humanity contemplates itself through the very action of replicating itself in the objects of its work, i.e. labor reinforces a sense of purpose and being. In the form of alienated labor, the reproduced form therefore turns into an outward and estranged phenomenon, which further alienates humanity from its own self-image, and therefore from itself. Consequently, individual humans also become alienated from each other (Marx 1992, 323-326). To quote Marx: "Thus through estranged, alienated labour the worker creates the relationship of another man, who is alien to labour and stands outside it, to that labour. The relation of the worker to labour creates the relation of the capitalist or whatever other word one chooses for the master of labour - to that labour" (Marx 1992, 331).

According to John Bellamy Foster, Marx's analysis of the alienation of labor is tied to the idea of labor becoming commodified and traded like an abstract product. The alienation of humankind from nature is the estrangement of human nature from nature itself. For Marx, nature was an extension of the human body. In his view, nature was the direct means of life and the object and tool of human activity. Alienation from nature therefore meant the disaffection of humanity from its extended, inorganic body. Marx thus understood that alienation itself occurred in a dual manner. Such an alienation entails both the alienation of humankind from nature and from its labor. Both, according to Marx, by necessity happen coincidentally. This simultaneity of losing touch both with the aspects of labor and with nature meant that individual humans have become socially estranged. By being alienated from their own human nature and from nature proper, 
individuals project this estrangement onto the social sphere (Foster 2000, 72-73).

This analysis of the dual alienation of workers from both nature and labor begins with an examination of the historical context of capitalism. Adam Smith's idea of primitive accumulation was pivotal to Marx's framework. Primitive accumulation in this context entailed the displacement of the peasantry and the enclosure of common lands. Both led to the creation of large estates, which exploited and dominated alienated labor. Domination of the earth was for Marx both the domination of the fertility of the earth itself and the domination of the people not in possession of land. According to Marx, it is therefore a fundamentally important aspect of capitalist and previously feudal societies that most of humanity is alienated in favour of a few property holders. At the time Marx formulated such ideas, the industrial revolution in Europe had led to a migration movement from the countryside to polluted cities, offering ample proof for his dire assessment of the working class (Foster 2000, 73-75).

Tillich (1998, 477-478) viewed Marx's theories on society as analogous to prophetic thought, where both viewed history as a battleground between good and evil and imagined justice triumphing over injustice. According to Tillich, both prophetism and Marxism assigned a meaning to history, one which is progressive and linear. For Tillich, this interpretation of Marxism showed how there is an innate affinity between Marxist thought and Christianity. More importantly, for Tillich the idea of alienation offered a crucial link between Marx and Christianity. In his interpretation, Marx thought that individuals have become dehumanized aliens to themselves, being objectified in a way that makes them just a measure of the labor force. With respect to Christianity, Tillich's existential outlook suggests that individuals have lost their true innate dignity as an image of God and are disconnected from others by the actions of the alienated individual. Tillich goes on to state that Marxism and Christianity agree on the historicity of humanity, whereby the historical context of human life defines its content. An escape from the alienated condition is, according to Tillich, for both historically contingent and dependent on the universality of escape from the condition of alienation. An individual cannot escape alienation alone. The process must be universal. Tillich therefore had an original view of Marx's idea of emancipation from alienation. A central part of Tillich's emphasis in this framework was his insistence on Hegel's statement that life cannot be reconciled if it is not first reconciled within itself. Without the experience of reconciliation, a personal escape from the alienated state, there cannot be any social reconciliation or a collective act of release from alienation (Tillich 1992, 264).

This is to say that estrangement is not only a matter of social structures or economic forces but also of personal experience and the existential condition of humanity. 
Tillich maintained that human alienation is absolute. Therefore, an alienated humanity cannot solve the problem of its own alienation. This is what Tillich called the "total depravity" of humanity. He did not, therefore, believe that any amount of human effort can overcome alienation (Cooper 2006, 65). This seems paradoxical, and to a certain extent it is, but the central notion here is effort, which would spring from the alienated actions of the individual. Tillich argued for a utopian approach that places its hope on transcending the current human condition. For Tillich (1984, 98-99), alienation is always primarily alienation from God, but he believed that life is, and always has been, ambiguous with respect to this alienation. For Tillich, the loss of a transcendent principle marks a dialectical process whereby there is a corresponding loss on the level of the immanent.

In an interesting way, Tillich therefore reversed the young Marx, who wrote in the 1844 manuscripts that estranged labor alienates humanity from its "spiritual", or human, essence (Marx 1992, 329). The young Marx (1992, 324-327) correspondingly viewed religion in a similar sense as production with respect to alienation. The more one invests in God, the less one has for him- or herself. If a worker invests himself/herself in an object, that part no longer belongs to him or her; it becomes part of the object, which is externalized. This external part of human labor is an autonomous power, which individuals must confront as a hostile and estranged power. In a way similar to religion, human imagination, intellect, and emotions become detached from the subject and are seen as the alien actions of divine beings. Humanity therefore loses a part of itself, which is projected onto the heavens.

Marx thus found the basis of the spiritual poverty or alienation of humanity in the material world, whereas Tillich found the basis of material poverty in the spiritual world. Both Marx and Tillich, however, viewed this estranged condition as both individual and collective. Individual humans add their own actions to the collective alienated state. Both however saw a dual poverty, which pertained to the material and to the spiritual, but understood it in different ways.

It is notable that Marx's theory of alienation holds within it a dialectical reversal of the usual ecological idea of humanity being only a part of nature. In Marx's view, nature is the inorganic part of human beings, not the other way around. What can be taken from this Marxian view is the awareness of a dual dependence on nature in human action. On the one hand, so as not to be alienated in a direct, reified sense, humanity requires a dialectical relationship with the natural world. We can see the appropriation of land in primitive accumulation as a form of alienation, and therefore as a precursor to the later developments in the colonization of natural life. 


\section{Non-Human Alienation and Marx}

Marx's concept of alienation can be extended to non-human animal life. However, it is noteworthy that his thoughts contained the idea of humanity as a shaper of nature, which entailed the use of the natural world as a tool. He was by no means a conservationist, and he actively discouraged viewing "nature" as a holistic whole. By this token, the later Marx, together with Engels, wanted to avoid the mystification of the relationship between humanity and nature. In the German Ideology, which for Althusser (1971, 61) marked the beginning of the "mature" Marx, they criticised the so-called True Socialist movement that flourished in the 1840s. Marx and Engels warned against an imagined mystic connection to the natural environment. By lampooning the True Socialist Rudolph Matthaï, they attempted to show that the idea of unifying humanity with nature through the spiritual experience of nature amounts to sentimental mystification. By pointing to the inherent conflict in nature, Marx and Engels moved towards a view of the natural world as a battleground between plants, non-human animals and humanity itself. They clearly did not hold the True Socialist ideal of harmony with the natural world as a reasonable position. Instead, they pointed to a conflict between "man and nature", which they held to be a pivotal part of history. By not acknowledging this central fact, the position holding an idealized view of nature falls short of realizing the reasons for the alienation of humanity (Foster 2000, 123-125).

Marx and Engels $(2010,473)$ further criticized the views that mystify human consciousness by thinking of it as a mirror of nature that only reflects the inherent awareness of nature itself, in which nature becomes self-cognizant. Again, for them, alienation from nature constituted alienation both from labor and from the role that humanity plays in transforming the earth (Foster 2000, 73). Here they echo Hegel, who in his Jena lectures of 1805-1806 stated that production is a means of reason's actualization of itself in the world (Avineri 1974, 90). Hegel, like Marx and Engels, could conceptualize the role of humanity in the world through the idea of production, and by doing this he highlighted the power of human agency regarding the natural world and its beings.

It is obvious that as science has progressed, we have a fuller picture of the natural world than either Marx or Engels. Therefore, this idea of an "inherent conflict" in nature has yielded to a larger picture of different levels of cooperation between various nonhuman actors. Moreover, the idea that humanity is in a constant state of struggle with its natural environment is today eerily prescient, as the relentless destruction of nature to produce commodities seems to portend the end of the current form of human life. 
Moreover, this picture of humanity in a constant position of using nature as a tool and an object does not tell of a deep ecological position that would aim to conserve nature. Certainly, for Marx, if nature is a part of humanity, its transformation by humanity via the means of production might be desirable. Although Marx's idea of alienation from nature could be criticized for its apparent anthropocentrism, its failure to consider the intrinsic value of other life forms, and at the very least for its partially instrumental relationship to nature, it still can illuminate the position of a dialectical relationship to our environment, a relation that can be interrupted by various external factors. These factors can be the relations of production, economic systems, practical solutions to the problems of survival, ideologies, and so forth.

I argue that this dialectical relationship can also help us to understand alienation in a more profound sense and should not be limited to the narrow viewpoint of humanity, but instead expanded to include non-human animals who dwell within and outside of human culture. All non-humans are in interaction with their environment and can be alienated from it by mechanisms similar to those that alienate humanity from the natural world. This alienation is not of course identical, but rather analogous. Marx's analysis, insofar as it describes the mechanisms of alienation, describes many effects of capitalism that resonate with all non-human animals that encounter human culture.

Peter Sloterdijk $(2018,75)$ has written of how humanity produces its livelihood partially by fossil fuels that are transformed into the products of agriculture by means of "bio-converters", that is, domesticated livestock. Livestock is therefore instrumentalized as machines that turn fuel into protein. Production animals are, hence, in the worst possible position with respect to alienation. Some live their entire lives in an environment that alienates them totally from any kind of relationship with the natural world. No wonder that Sloterdijk has termed livestock animals "the new proletariat".

As Marx $(1992,325)$ wrote, the more workers produce, the less they become; likewise, the more value they create, the more worthless they become. Is this logic not brought to an absolute culmination point in factory farming, where non-human labor is in absolute deprivation and in a state of utter alienation? For an example of this estrangement, one can take the manipulation of the daylight cycle of broiler chickens to encourage eating and to maximize the growth of body mass. Here, the exploitation of life arrives at a limit that would be hard to imagine if it were not true. Again, Marx's $(1992,323)$ statement on the commodification of the laborer seems chillingly accurate: "The worker becomes an even cheaper commodity the more commodities he produces." The alienated "object" of human calculation and exploitation becomes all the cheaper the more workers produce themselves as a commodity. Marx further states 
that, of course, labor produces miraculous things for the rich, but at the same time it produces privation in the workforce. He writes of alienated production: "It produces beauty, but deformity for the worker. It replaces labour by machines, but it casts some of the workers back into barbarous forms of labour and turns others into machines." (Marx 1992, 325-326.) Again, the alienated production of non-human life brings forth the worst excesses in this line of development.

Marx (1992, 329) wrote in the Economic and Philosophical Manuscripts that non-human animals also produce things, like nests, damns and other dwellings. However, non-human production is for the immediate needs of survival. Thus, it is unlike human production, which takes place "universally". That is to say, humanity ideally has the capacity to creatively reproduce any form in nature, whereas non-humans produce according to the dictates of their species. As previously stated, the alienation of humanity from its labor leads to the estrangement of its species-being. This means that humanity loses the ability to reflect upon itself through the creative process of production. Thus the individual becomes alienated from others, and all become alienated from the essential qualities of humankind (Marx 1992, 330). Further, the creation of estates through primitive accumulation during the Middle Ages had its basis in the division of society. Marx argued that this division disconnected humanity from its essence, and thus alienated humanity from its essential nature, from what makes it human. Marx therefore called the Middle Ages the "animal history" of humanity $(1992,148)$. Thus, through capitalism human production loses what Marx considered its essential humanness. However, non-human production is even more totally alienated by capitalism and therefore becomes simply forced re-production.

This universal, or objective, production was for Marx a pivotal part of humanity's creative capacity, what he called species-being. He described this capacity in the following way:

- It is therefore in his fashioning of the objective that man really proves himself to be a species-being. Such production is his active species-life. Through it nature appears as his work and his reality. The object of labour is therefore the objectification of the species-life of man: for man reproduces himself not only intellectually, in his consciousness, but actively and actually, and he can therefore contemplate himself in a world he himself has created. In tearing away the object of his production from man, estranged labour therefore tears away from him his species-life, his true species-objectivity, and transforms his advantage over animals into the disadvantage that his inorganic body, nature, is taken from him.

(Marx 1992, 329) 
In his article "Reclaiming Species-Being: Toward and Interspecies Historical Materialism", Mathieu Dubeau $(2018,192)$ has described how Marx's materialist ontology is more open to the evolutionary models of animal cognition than Marx himself might have thought. Dubeau sees a contradiction in Marx's idea of exceptional human abilities and his commitment to the science of biology. According to Dubeau, we can escape this aporia by taking species-being as a central category of interspecies encounters, which overcomes the traces of Hegelian idealism in Marx's thought that would emphasise the predominance of the ideal over the material. According to him, the expansion of the concept of species-being makes it possible to understand the capacities and subjectivities of non-human animals, which have been neglected in past Marxist theory (Dubeau 2018, 187). That is to say, by extending Marx's ideas about species-being to include non-human animals, we can more readily approach the political and ethical questions of interspecies encounters.

Dubeau $(2018,193)$ notes that non-human animals working in a professional capacity and in agriculture are alienated in a similar manner as humans working in the labor force, and he correctly notes how this forced labor scars them psychologically and physically before death. As I understand it, Dubeau is writing mostly about the alienation that laborers experience from the product of their labor. That is, when cattle are raised for slaughter, they are alienated from their own flesh by the process in which they eventually become meat.

Keeping this in mind, we should make note of the fact that alienation from the environment is different for different classes. As Paul Burkett $(2007,88)$ has noted, for humans the proximity to the natural environment is quite different for laborers and their families than for those who gain the most from owning the means of production. I would claim that not all non-human animals who are put to "work" are alienated in a similar way either. It would be somewhat strange to claim that a therapy dog who "produces" affection and encouragement for children while they read aloud is alienated in a similar way as a factory-farmed pig. In addition, companion animals work in a reproductive capacity, whereby they enable their human companions to de-stress and again "produce" affection and care. Non-human work is, in this way, like human work: the mode of labor is crucial with respect to the mode of alienation.

\section{Alienation and Violence}

To complement this view of estrangement, we should note how and why alienation could be conceptualized as violence. The forced alienation of both humans and non- 
human animals is obviously violence in the strict Levinasian sense, where violence is a one-sided act and where one actor takes it upon him- or herself to operate in a way that makes all others purely recipients of this action. Violent acts are actions that one must endure without collaborating with them (Levinas 1990, 125). Shifting focus from immediate outbursts of violence to slower, more insidious forms of violence is another way to examine the idea of alienation from nature. The literary theorist Rob Nixon has fleshed out an inclusive theory of violence that concerns the environment and contextualizes those of its various forms, which usually do not come into account when discussing violence. In his 2011 book Slow Violence and the Environmentalism of the Poor, Nixon $(2011,2)$ describes his idea of "slow violence". Unlike the immediate and more spectacular forms of faster violence, slow violence is usually hidden and its duration is long. Therefore, it is not usually even considered as violence. As such, the idea of slow violence shifts focus from immediate, brutal acts of violence to cumulative and incremental acts. These systemic forms of violence, like the pollution of rivers or soil or the dissemination of radioactive material in natural environments, highlight the idea of violence as something other than immediate. Perceiving the speed of violence therefore requires a shift in focus.

Nixon (2011, 150-151) writes of "unimagined communities", a principle of exclusion which leads to directly physical as well as imaginative displacement of communities through an assault on natural resources, land, animal life, and so forth. This exclusion leads to a hierarchy of suffering, where some suffering goes unrecognized due to its distance from the privileged class who can form the kinds of narratives of suffering that are found acceptable to the gatekeepers of legitimate suffering and victimhood (2011, 47-48).

Whereas domesticated and factory-farmed "livestock" might be alienated from nature within the capitalist economy, the "unimagined" non-humans that live in natural environments are not taken into account and their lives are not included in any meaningful economic calculations, as is evident from the interminable wave of extinction of animal life.

The status of the victim in the never-ceasing cycle of environmental violence is rarely granted to non-humans. Even though non-human life in many of its forms may be protected, these forms are not brought under the class of victimhood. Even in the case of the uncannily humanlike Bornean orangutan, which as a species is nearing extinction due to the high demand for palm oil in consumer products, conservation efforts are secondary to the profit-seeking drives of multinational corporations (Johnston 2016). The orangutans are here truly unimagined, their lives completely reduced to a 
position of invisibility, while their habitat is brought into the sphere of private property and destroyed.

Could we not say that this unimagining and the destruction of the jungles of Borneo are effectively alienating orangutans from their environment? This alienation, though, is occurring in a different way than it is for "livestock". After all, like in the case that Marx presented regarding humans, orangutans have a direct means of life that is their habitat, and their alienation from this habitat means a disaffection from what can be called their extended body. The dwindling of a species means, by necessity, an estrangement that is projected onto the social sphere, due to the fact that the fewer members of the same species there are, the more the chance of encountering one diminishes.

The speculative realist philosopher Timothy Morton $(2007,93)$ has written of the environment as an abstract space and as a colonialist fantasy. In this mode of colonization, natural environments, including the molecular level of DNA and other biological functions, are something to be financially or scientifically exploited. The colonization of nature in this way is therefore a direct commodification of biological processes. Thus, the relationship of humanity and the environment is made one-sided, instrumentalized, and brought within the sphere of direct financial exploitation.

Morton's analysis of imperial geography at the level of DNA brings the idea of alienation and private property to the lowest biological level. Destroyed animal life that is "unimagined" as a superfluous component of exploitable nature is, on the one hand, an unintended by-product of the colonization of nature; on the other hand, the likewise "unimagined" livestock is colonized at the level of the most minute biological processes, including genetic, behavioural and physical processes. Here, the objectification of natural processes yields a form of estrangement that unites non-humans both within and without human culture. Objectification by humanity paves the way to the colonization of non-humanity and divorces the non-human from their species-specific traits and needs. The unimagined empty space that humanity has created amid "nature" is thus both a cause and an effect of human alienation. The concept of the empty space, which is formed through the alienation from nature, is here crucial. Were humanity unalienated from nature, the whole idea of so-called empty natural space would be impossible, as would the idea of brutal and total biological domination of animals as livestock, resources or an excess to be discarded. Alienation in humanity breeds alienation of other species as well. 


\section{Tillich's Existential Alienation}

As we have seen, for Tillich estrangement had three components, which reinforce each other. Firstly, humanity has lost confidence in its Ground of Being, which for Tillich means a basic trust in God. This existential condition, Tillich believed, leads humanity to an anxiety that enslaves us. In an alienated anxiety, we are unable to care for others and for ourselves; this apprehension captures us and makes us unresponsive to those around us. Secondly, humanity alienates itself by its hubris, in which the Ground of Being is replaced by the self-elevation of individual humans. Instead of nurturing relationships with those around us, we anxiously turn inwards and make ourselves the centre of the universe. Therefore, this "demonic structure" feeds off the anxiety of individuals and makes a healthy self-affirmation into destructive self-elevation. Thirdly, there is concupiscence, a desire for finite things, which means a consuming human desire for contingent possessions. These objects purport to fill in the gaps experienced by the anxious, self-elevated individual (Cooper 2006, 92-93). These things, these fixated objects of desire, are a distraction from the experience that alienation breeds. Estrangement is therefore a self-reinforcing cycle that gains power with every rotation.

While being wary of various forms of the directly moralizing dimensions of the concept of sin, Tillich (1991, 200-202) still holds that any proper analysis of alienation requires the concept of $\sin$. Tillich states that $\sin$ is the personal dimension of the "universal destiny of estrangement". In Tillich's dialectical model of alienation, it is a question of an individual's freedom and guilt, but at the same time this alienation is the inexorable fate of humanity. For Tillich $(1966,156-157)$, the concept of sin, which is always in the singular, was therefore not the breaking of the commandments of God, but rather the universal separation of the human individual from him- or herself, from others, and from the ground of human life. Further, this separation is alienation. For Tillich, sin is therefore alienation and alienation is sin.

Regardless of this insistence on the word sin, if not on the traditional meaning of the concept, Tillich $(1991,203)$ has also criticized the Judeo-Christian tradition for being too interested in the singular guilt of the individual. Nevertheless, at the same time he has accused this tradition of not being interested enough in the guilt brought upon the collective by the "universal destiny" of humanity, which is alienation. Tillich writes further that although particular persons might not be directly guilty of the crimes committed by a tyrant, they still might be guilty of participating in the universal condition of humanity via their estrangement from its essential being. Moreover, by this token individual alienation that becomes collective contributes to the possibility of there being 
tyrants in the first place. Tillich thought that humanity has an essential capacity for goodness, but this nature, this natural propensity, is lost through alienation.

Tillich viewed alienation as a structural part of humanity, which he termed the "structure of destruction" (Tillich 1991, 204-205). He also had the idea that just by being active in society, one bears part of the responsibility for the worst excesses, not only of that society, but of other societies that are in interaction with it. He thought that falling under a condition of tyranny was a symptom of the universal estrangement of humanity, and that therefore individual humans were partially responsible for the collective actions of the whole, even though they might be the victims of some resulting action (Tillich 1991, 204). For Tillich, therefore, society shows itself as a network of relationships and ethical obligations. The condition of responsibility is an essential part of any relationship, and therefore it has a heavy existential weight.

Morton (2007, 91-93) has criticized the idea of capitalism for being inherently materialist, by pointing out how capitalism does not respect matter, but instead acts like "idealism gone mad" by destroying the material environment for profit. The commodification of nature works as a catalyst of this objectification process and the takeover of the environment as an alienated commodity. Tillich $(1991,205)$ wrote that in using language, humanity has the possibility to objectify its environment and itself. By using the freedom of this structure of speech, individuals can lose their actual connection to either themselves or their environment, and alienation from either is followed by alienation from the other as well. Tillich writes that those theories of humanity that describe humans only as a thinking, analytical beings, or as cognitive subjects that strive to control reality, only manage to describe human alienation. Furthermore, the subject's approach to all things as objects of control leads to the self-objectification of the subject itself. To be precise, the subject, which is a part of the world, strives to control the world, and therefore itself, as an object. It is thus the case that the approach of the calculating subject, who approaches everything through the methods of perception, analysis, and control, is always alienating.

Tillich $(1991,210)$ regards the theoretical and practical approaches to humans as objects to be inherently evil. If we broaden this approach to non-human beings, we can see how Tillich's approach works regarding the alienation of all animals, humans and non-humans alike. As Marx analyzed, the alienation of human labor alienates humanity from nature, which, compounded with the idea of objectifying others, leads to a dual alienation. The calculating subject, who approaches natural environments and non-human beings as objects, is at the same time the victim of his or her own calculations. Therefore, everything is calculable in terms of finance, even the pain and 
suffering of other animals, both human and non-human. This calculation of suffering and victimhood furthers the alienation of humanity and ripples throughout our environment, which reacts to disjointed attempts to "manage" it.

Just as the calculations of profit from various forms of environmental destruction further alienation, it is this alienation that in turn becomes the kind of slow violence that Nixon described. As the alienation of both humanity and non-humanity progresses, the violence that is immediate becomes indirect and is further hidden from view. One person throwing his or her trash into the sea or onto the beach does not create a polluted coastline, but in the end this action contributes to the problem by actively taking part in its creation. As Nixon $(2011,11)$ has pointed out, time plays an intricate role in slow violence. Violence becomes a phenomenon that is decoupled from its origins due to the passage of time. I claim that alienation is a medium of this decoupling, whereby any analysis of our own participation in slow violence becomes quite difficult due to our inability to see past our own alienated state.

In his book The Courage to Be, originally published in 1952, Tillich (1980, 45-46) writes of the anxiety that both humanity and non-humanity feels. Tillich sees anxiety as a lack of objects to focus on. To quote Tillich, "its object is the negation of every object" (Tillich 1980, 45). All animals (including humans) can feel the weight of this anxiety, which determines their possibilities of action and thus makes them helpless and despondent before the threat that they must face. Because this anxiety is concentrated on the lack of an object, and therefore on the threat itself rather than its origin, responding to it seems impossible, as it is non-being. Against this dilemma, Tillich posits God as the Ground of Being.

Going even further, in Tillich's existential theology human alienation leaves us in a state of fear and anxiety of non-being that is transformed into a horror of death. For Tillich, this condition is common to all finite beings and is omnipresent. The anxiety felt by Christ before his death confirms that this horror and angst penetrates even the territory of the divine, and thus it is universal and in all domains. Human alienation turns the anxiety of non-being into an existential evil. Through the lens of alienation, humanity looks at the natural process of annihilation and perceives finitude itself as evil (Tillich 1991, 211). Here, the Hermetic maxim "as above, so below" receives a grim twist, as it is not the radiant beauty of heaven that is reflected on earth; instead, the existential "animal" horror, fear and panic of finitude is reflected from the biological basis of creation back to the divine. The theological and ethical implications of this idea are obviously enormous, as in a Hegelian twist it is the corporeal level of existence that is reflected back to the godly. One could claim, therefore, that in Tillich's thought the suf- 
fering of alienated creatures, or creation, not only takes part in, but also constitutes, a cry to the heavens that God himself is only one part of. It is thus not that we should see the suffering of Christ in tormented creatures: a far more profound theological position would be to see Christ only as a part of the suffering of creation.

\section{Alienation and the Possibility of Hope}

Although this vision of the fallen and alienated condition of humanity and non-humanity alike is a bleak vision of reality, it is not without hope. It is possible to find through it a shared basis of existence that can work to empower ethical ideals of cohabitation and to realise some of the inherent violence that alienation entails. According to Tillich's analysis, Christianity and Marxism are both opposed to a harmonistic optimism, which would claim that humanity could overcome its "fallen" condition via individual effort. Tillich calls this a "Pelagian" optimism, referring to the Pelagian heresy that claims that humanity was not tainted by original sin (Tillich 1998, 479).

In "Reclaiming Species-Being", Dubeau $(2018,203)$ writes about how non-human animal actions problematize Marx's concept of species-being, which Marx ascribed only to humans. Dubeau $(2018,188)$ has, I think, correctly argued that the concept that Marx thought pertained only to humans could and should be extended to other animals as well. In Dubeau's reformulation, species-being comes to designate the recognition of the interdependence of all beings. It is cognizant of the fact that the lives of all beings are entwined and that species-being should denote a relationship between beings. Seen in this way, Dubeau argues that the concept of species-being should be seen as a process of sharing that promotes an interspecies flourishing. As stated by Dubeau $(2018,205)$, reading the concept in this new way enables us to see the importance of our relationships extending beyond the human species and makes possible a flourishing that enables us to overcome the speciesist trappings of traditionally humanist Marxism. This perspective is, in my view, in line with Marx's thought, which emphasized material science. Knowing what we know today, Dubeau's model is the logical step forward, or indeed sideways, for Marxist theory.

In a very interesting way, this move of ascribing value and importance to cohabitation, relationships and the shared base of existence within the context of Marxist theory reflects Tillich's thoughts in a fascinating way. It is almost a utopian move, but one that seems to require very little, only a shift in perspective. Tillich (1991, 325-331) wrote that humanity had - at times - fulfilled some historical optimistic expectations, even though in a fragmented fashion. In movements like the growth of democracy, 
or a "belief in the original unity of all human races" (Tillich 1991, 329), one can sense this possibility for hope, even though these moments of hope might be fleeting. He further thought that due to the terrors of the $20^{\text {th }}$ century, this communal hope was in short supply. Despite his bleak outlook, Tillich had "in some respects" hope that human ingenuity, the ability to control natural resources and technological advancement would help humanity progress beyond its current conditions. Collective hope might be even harder to come by today, when the entire planet, yet again, seems to be heading towards a cataclysmic environmental collapse. It is hard to see the ability of humanity to control some aspects of its shared environment as something that fits the definition of "progress", if we consider the current wave of mass extinction.

However, Tillich (1987, 329-331) further stated that progress towards a new good that vanquishes an older type of evil will create a new evil based on the new good. He did not believe that there was some perfect endpoint for humanity, some ultimate earthly paradise that humanity is striving towards, but instead that humankind struggles throughout history for the best possible outcome. This struggle is one of alternating moments of progression and regression, but the progressions, the victories, provide us with a glimpse of what Tillich calls the "Kingdom of God". This is not something that follows some apocalyptic event that ends history, but rather a glimpse of the eternal through acts of joy, love, and the experience of truth or the holy. For Tillich, this Kingdom is here and now, and not off in some imaginable, or unimaginable, future. Further, Tillich states that this experience of the eternal is something that we share among all creation, not solely with humanity.

According to Tillich, then, in a theological sense it is not only the horrible and terrifying aspects of existence that we humans share with non-humanity, but the experiences of grace as well. From this idea, one can gather that shared experience constitutes both a possibility and an obligation for humanity to take into consideration other beings, but not, however, in the alienating way as objects of calculation. Rather, this should be done in a spirit of equality and kinship to other animal life. The analysis of Marx is one tool for understanding why humanity is alienated, and it can be used to understand estrangement in a wider context, also as an opportunity to rethink the rapid and slow violence that we as a collective perpetrate.

This new understanding may enable us to act in a way that, while still alienating, proceeds in a different, perhaps less harsh, mode. What we can hold on to in Tillich's philosophy, even without accepting its theological assumptions, is the idea of approaching alienation as a dialectical problem. It is not a problem of individual effort, nor a problem of society or economics, but both. By accepting our own personal 
powerlessness against societal estrangement, we can perhaps begin a proper analysis of this dialectical structure without the eschatological framework that is the hallmark of vulgar Marxism and progressive liberalism. Working with this idea of alienation of humanity and non-humanity, we can open new avenues of investigation into the question of various forms of slow violence.

Bruno Latour (2017, 285-287) writes in Facing Gaia of our own current epoch, which he considers to be the time after the rupture of the apocalypse. He urges us to "free ourselves of the infinite", which for him consists of realizing that we live in the "time of the end", and of therefore understanding the limitedness of time (Latour 2017, 285). For Latour, like for Tillich, this apocalyptic world is not some new creation that emerges at the end of this one, but a new way of approaching our current world. This for Latour entails the turning of the historically Christian gaze away from the supernatural heavens downwards towards the material natural terrain. As we have seen, Tillich's project as a theologian and a philosopher was in part an attempt to do just that.

According to Tillich $(1966,157)$, humanity is separate from other animals not because of its alienation, but because it has a sense of its own alienation. This idea however is problematic in the sense that, although we know that non-human animals do not use linguistic concepts, we simply do not know whether they experience alienation in a similar way as humans. If a dog feels pain, it cannot verbally state that it "radiates from the abdomen", but we can be sure that it knows physically where the pain is located. Tillich's emphasis on human existential suffering seems, therefore, to ring slightly hollow. If it is based on humanist nostalgia, it is unsubstantiated and morally questionable. If we were to imagine a hedgehog that loses her burrow because a house has been built on top of it as feeling sad, rootless, vulnerable, frightened, and alienated, we would probably be closer to the truth of alienation than by stating that it is only humanity that has the possibility to reflect on it. This may be so, but is there an inherent value in verbalizing it? Tillich's own thought makes possible a far more varied and interesting picture of human and non-human life than this kind of general emphasising of "the human".

Combining the ideas of young Marx with Tillich's critique of his theory of alienation does not undermine Marx's arguments. Rather, they work in tandem to complete the ideas that the young Marx's humanist position could not fully embrace. As Dubeau has shown, Marx's humanism was inconsistent with our current knowledge of the capacities of non-human animals. By combining a new understanding of the possibilities of animal life with the ideas of Tillich, which take non-human animals to be in a spiritual position analogous to humanity, we can see a shared foundation of life, not as a 
hierarchical relationship of abilities, but as an entwined involvement, one which opens up yet more possibilities for cohabitation. The importance of taking alienation as an analytical tool lies in its power to render visible the inherent violence of our relationship to non-human life of all kinds. A purely rational relationship to those around us reduces not only our own capacities, but those of others as well. Symbols like the Kingdom of God might not be to everyone's taste, but they nevertheless point towards a utopian conception of a shared existence. While such an existence might never be realized, its utopian ideal is nevertheless important in a time when our alienated actions are bearing dreadful fruits. Granted, the thinking of the young Marx is not perhaps as impressive as the awesome intellectual prowess of the mature Marx; however, he did engender a way of seeing the relationship of humanity to its environment that was unique and has borne fruit that Marx himself might not have expected.

\section{Conclusion}

Returning to the previously mentioned example of the sea turtle on the beach, we can discern the dialectic of the essential alienation of the collective and what Tillich terms sin, the actions that flow from the estranged will of the individual. The viewpoint of the turtle is absolutely immersed in the alienated actions of humanity, which are perpetually destroying the environment, thereby producing a world that is alien and unworkable via older methods of survival. This perplexing alienated landscape is different for a sow in a gestation crate. Unable to move, it is exploited like a machine, with her children experiencing terrible fates at the hands of a machine that makes them into alienated objects. To truly respond to this terror, this existential horror, one must be able to face it and stand firm when this machine of alienation claims its business-as-usual approach. We could analyze this violence in a myriad ways, of course, but unless we consider that the inability to respond to this cruelty has an existential component, we might not be able to see the full horror of it. If we take as a starting point the potential for production inherent in humanity, the alienation of animals is a direct product of this human power of production, or of the actualization of humanity in the world. To go even further, is not Tillich's idea of total depravity then strangely appropriate? After all, the more humanity actualizes itself, the more it shapes the earth, the more it produces and the more it destroys. We can therefore see human estrangement as a self-reinforcing cycle, one which not only extinguishes life, but also holds on to its destructiveness at its own cost.

In this article, I have shown how Karl Marx's analysis of alienation can be ex- 
tended to non-human beings. I have also discussed how reading Paul Tillich together with Marx can expand and deepen this analysis by adding new existential dimensions to it. Further, I have considered the application of the concept of alienation to Rob Nixon's concept of slow violence and shown how it is compatible with it. Tillich's ideas of our shared suffering and our shared experience of the divine open up new possibilities for imagining a completely new horizon in which the theological is connected to the political in the spirit of protection and conservation; but at the same time, it also considers the inherent negativity of the human condition. Whatever one thinks of the theological content of Tillich's thought, his ideas about the remoteness of final reconciliation and of coping with alienation, in my analysis his views present one opportunity for reimagining the horizon of possibilities and responding to the questions of estrangement. In this way, it can help us refocus our eyes on alterity, by reimagining the world anew through the ideals polyphony, non-violence, and deference.

\section{REFERENCES}

Althusser, Louis. 1971. For Marx. London: Allen Lane.

Avineri, Shlomo. 1974. Hegel's Theory of the Modern State. Cambridge: Cambridge University Press.

Burkett, Paul. 2007. Marx and Nature: A Red and Green Perspective. Chicago: Haymarket Books.

Colletti, Lucio. 1992. "Introduction" in Early Writings, by Karl Marx, 7-56. London: Penguin Books

Cooper, Terry D. 2006. Paul Tillich and Psychology: Historic and Contemporary Explorations in Theology, Psychotherapy and Ethics. Macon: Mercer University Press.

Dubeau, Mathieu. 2018. "Reclaiming Species-Being: Towards an Interspecies Historical Materialism." Rethinking Marxism: A Journal of Economics, Culture \& Society 30:2. 187-207. https://doi.org/10.1080/08935696.2018.1502307

Foster, John Bellamy. 2000. Marx's Ecology: Materialism and Nature. New York: Monthly Review Press, 2000.

Johnston, lan. 2016. "Orangutans face complete extinction within 10 years, animal rescue charity warns" The Independent, August 19, 2016. http://www.independent.co.uk/environment/orangutans-extinction-population-borneo-reasonspalm-oil-hunting-deforestation-rainforest-a7199366.html

Latour, Bruno. 2017. Facing Gaia: Eight Lectures on the New Climatic Regime. Cambridge \& Medford: Polity Press. 
Lévinas, Emmanuel. 1990. Difficult Freedom: Essays on Judaism. Baltimore: John's Hopkins University Press.

Marx, Karl. 1992. Early Writings. London: Penguin Books.

Marx, Karl and Engels, Frederick. 2010. Collected Works Vol. 5. Dagenham: Lawrence \& Wishart.

Mészáros, István. 1970. Marx's Theory of Alienation. London: Merlin Press.

Morton, Timothy. 2007. Ecology Without Nature: Rethinking Environmental Aesthetics Cambridge \& London: Harvard University Press, 2007

Nixon, Rob. 2011. Slow Violence and the Environmentalism of the Poor. Cambridge \& London: Harvard University Press.

Tillich, Paul 1966, The Shaking of the Foundations: Hammondsworth: Penguin Books.

Tillich, Paul. 1980. The Courage to Be. Glasgow: William Collins, Sons \& Co.

Tillich, Paul 1984, The Meaning of Health: Essays in Existentialism, Psychoanalysis, and Religion. Ed. by LeFevre, Perry. Chicago: Exploration Press.

Tillich, Paul. 1991. Theologian of the Boundaries. Ed. by Taylor, Mark Kline. Minneapolis: Fortress Press.

Tillich, Paul. 1992. Main Works - Hauptwerke Vol. 6. Theological writings. Ed. by Ratschow, Carl Heinz. Berlin \& New York: De Gruyter - Evangelisches Verlagswerk $\mathrm{GmbH}$.

Tillich, Paul. 1998, Main Works - Hauptwerke Vol.3 Writings in Social Philosophy and Ethics. Ed. by Sturm, Erdmann. Berlin \& New York: De Gruyter - Evangelisches Verlagswerk $\mathrm{GmbH}$. 